\title{
In Praise of Janus!
}

\section{Arthur M. Michalek}

Published online: 9 April 2013

(C) Springer Science+Business Media New York 2013

It is with great pride and a certain amount of trepidation that I pen my first editorial for the journal. I follow in the footsteps of two great educators: Drs. Richard Bakemeier and Joe O'Donnell. Each in their own inimitable way has been responsible for the growth of the journal and its recognition as the source for thoughtful presentations and reflections in the field of cancer education. At this time of transition, I am reminded of the Roman god Janus who is the god of gates and doors, beginnings and endings, of transitions. He is represented by a double face, each looking in opposite directions - one to the past and one to the future. The month of January is named in his honor since it is a time to look at past accomplishments and to look to the future and set new goals. The journal was founded in 1986 by Dr. Richard F. Bakemeier and his Editorial Associate and wife, Alice Holyoke Bakemeier, RN, MS, the former editor of The Diabetes Educator. The first issue of the journal ran 57 pages and contained six articles, four book reviews, three letters, and one editorial. Four of these articles presented the status of training at the NCI, ACS, and UICC. The lead article was written by Dr. Margaret Hay Edwards on the development of education and training programs at the National Cancer Institute from 1938 to 1982. Dr. Edwards had a long and distinguished history in cancer education, and it is in her name that the AACE's most prestigious honor is named. In his inaugural editorial, Dr. Bakemeier cited the challenges faced in cancer treatment and education as well as the future role for the Journal of Cancer Education. He cited the then prevalent "pessimism among both professionals and the public about the chances for cure or at least high quality life after a diagnosis of cancer." Dr. Bakemeier cited the need to develop more responsive educational programs for primary care providers, the need for graduate curriculum time devoted to oncology, and a call for

A. M. Michalek $(\bowtie)$

Health Policy, D’Youville College, Buffalo, NY, USA

e-mail: Arthur.Michalek@RoswellPark.org

A. M. Michalek

Roswell Park Cancer Institute, Buffalo, NY, USA transdisciplinary cancer education. He opined that this new publication, the Journal of Cancer Education, "will facilitate the dissemination of proven, successful cancer education methods and will stimulate the development of innovative approaches to the cancer education needs of learners at all levels." It is now 27 years later, and some of these goals have been achieved while others will require constant and continual attention. A factor responsible for much of our success has been the journal. Conceived at a time when there were limited opportunities for us to publish results of our efforts in cancer education programs, the journal has and will continue to provide an outlet for us to disseminate our findings and provoke thought.

Dr. Joe O'Donnell inherited a strong, adolescent journal and fathered it through to a vibrant young adulthood. He has not only remained true to the founding principles of the journal, but carefully nurtured its intellectual growth. The journal has grown both in size and stature. Each issue now runs approximately 200 pages and contains over two dozen research articles. In addition to recounting pedagogical adventures, it also includes thoughtful and thought-provoking pieces in the Reflections section. Of course, the highlight of every issue is Joe's editorial. It is through these missives that he has demonstrated to us the multidimensionality of cancer education. That the reporting of cancer education programs is far more than hypotheses and confidence intervals and that we must think outside the box and, often, outside our limited comfort zones. That we need to interpret and apply findings from fields as diverse as philosophy, history, business, and any other field that explores and presents new cognitive concepts. Where else can you read an Editorial that cites a poem on intelligence, a treatise on the art of medicine, and a Dr. Seuss book? Joe is a true thought leader. We will all miss his insights, and you will all learn how to tolerate or ignore mine.

So... what lies ahead for the journal? Even though I am not a physician, I will do my utmost to uphold the Hippocratic Oath and "abstain from doing harm." The journal will continue to publish high-quality articles on the philosophy and practice of cancer education. It will also continue and 
expand its role of provocateur by publishing entertaining and challenging review articles. Perhaps we can persuade Joe to lead off this series and expose us to thoughts we would never have thought by ourselves. The journal will be guided by an expanded role for the deputy and associate editors. These individuals will not only assist with the continued growth of the journal, but play a larger role in recruiting new voices to our pages to present cutting edge reviews and opinions in all disciplines of cancer education. That said, the ultimate direction of the journal will be dictated by you - the authors. Rest assured that you will find open minds to your thoughtful, impassioned works. The journal was started because cancer educators had difficulty finding an outlet to disseminate their works. Many have published their first works in this journal. I hope that the journal will continue to be a nurturing environment for young investigators and it will continue to launch the careers of those destined to become master educators.

I began this Editorial in praise of Janus, but (pardon the awkward homophone) it could have been entitled "In Praise of Janice." Janice O'Donnell is Joe's better half. I have known her for years and can readily attest to her intelligence and charm. I extend to her our thanks for sharing Joe. It has definitely been our pleasure and one that I hope we will continue to savor.

One of Joe's favorite quotations is from Isaac Newton: "the reason I see further is that I stand on the shoulders of giants." Well Joe, you are one of those giants, so prepare to have your shoulders scuffed up because I am climbing on board.

I look forward to serving you all. Be well.

Arthur M. Michalek, PhD, FACE 